\title{
BULBOPHYLLUM BREIMERIANUM (ORCHIDACEAE), A NEW SPECIES FROM BORNEO
}

\author{
J.J. VERMEULEN ${ }^{1} \&$ A. VOGEL ${ }^{2}$
}

SUMMARY

Bulbophyllum breimerianum from Borneo is described. It is most similar to B. macranthum Lindl., B. praetervisum J.J. Verm., and B. grandifolium Schltr.

Key words: Bulbophyllum breimerianum, Borneo.

Among the Bornean material previously identified as B. macranthum Lindl., a third species of similar appearance was collected in East Borneo in 1991 next to B . praetervisum J.J. Verm. (see Vermeulen, 2002). The plant is in cultivation in Leiden Botanic Gardens and has yielded the type material when it flowered.

Bulbophyllum breimerianum J.J. Verm. \& A. Vogel, spec. nov. - Fig. 1

A Bulbopyllo macrantho et $B$. praetervisso labii basi cornibus duobus retrorsis, stelidiis ala rotundata secus marginem inferiorem differt. - Typus: Hort. Leiden 913636 (L), Indonesia, Kalimantan Timur, Sangkulirang Peninsula.

Roots scattered along the entire rhizome. Rhizome 4-7 mm diam., sections between pseudobulbs $2.5-5.5 \mathrm{~cm}$ long, bract fibres rather thin, persistent. Pseudobulbs distant, ovoid, $1.7-3$ by $0.8-1.2 \mathrm{~cm}$. Petiole $1-1.8 \mathrm{~cm}$. Leaf blade elliptic to obovate, $9-13$ by 2.7-4.2 cm, index (length/width) 2.8-3.5; obtuse. Inflorescence 5-6 cm, 1-flowered. Peduncle 1-1.5 cm, bracts 4-6, covering the peduncle. Floral bracts tubular, 7-9 mm, acute. Pedicel and ovary 35-40 $\mathrm{mm}$ long, basal node on a c. $8 \mathrm{~mm}$ long stump. Flowers not resupinate (with the lip turned upwards), widely opening. Median sepal spreading with recurved top part, elliptic, 20-25 by 7-8 mm, index 2.5-3.6; acute to shortly acuminate, base rather narrowly attached; glabrous. Lateral sepals free, recurved but converging and (almost) touching towards the tip, top part somewhat curved inwards, oblique, ovate-triangular to triangular, 22-23 by 7-9 mm, index 2.4-3.2; base widely attached; otherwise as the median sepal. Petals spreading or somewhat reflexed, elliptic to ovate, $17-20$ by $6-8 \mathrm{~mm}$, index $2.1-3.3$; subacute to shortly acuminate, base narrowly attached; glabrous. Lip recurved \pm half-way, triangular-hastate with a drawn-out,

1) Nationaal Herbarium Nederland, Universiteit Leiden branch, P.O. Box 9514, 2300 RA Leiden, The Netherlands.

2) Hortus Botanicus Leiden, Universiteit Leiden, P.O. Box 9516, 2300 RA Leiden, The Netherlands. 


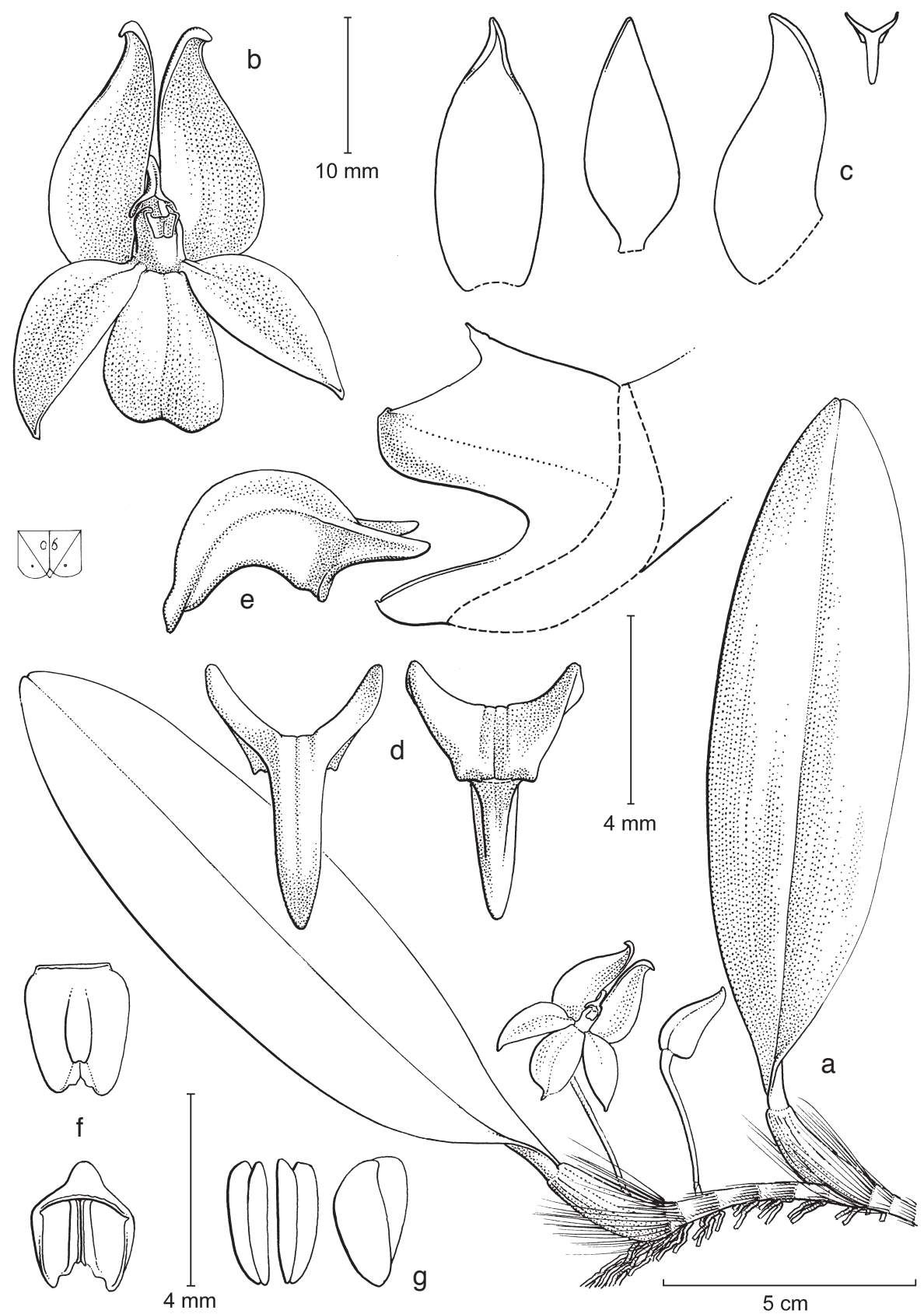

Fig. 1. Bulbophyllum breimerianum J.J. Verm. \& A. Vogel. a. Habit; b. flower; c. flower analysis, from left to right: median sepal, petal, lateral sepal, lip; d. lip, left: adaxial side, right: abaxial side; e. column and lip, lateral view; f. anther, above: abaxial side, below: adaxial side; g. pollinia, left: two pairs, right: a single pair (all Hort. Leiden 913636). 
linguiform top part, $4-6.5$ by c. $4 \mathrm{~mm}$, index $1.6-1.7$ (all without artificial spreading); obtuse, margins folded into 2 retrorse, thick, \pm straight, horn-shaped projections above the base when the lip is observed in lateral view; thick, glabrous; adaxially concave towards the base, convex towards the tip; abaxially with a retuse ridge over most of the length of the lip, top part flat. Column 5.4-6 mm long, \pm straight in profile, stigma without teeth at the base, inside with 3 keels: one on the back wall and two on the front wall; column foot without ridges. Stelidia porrect, deltoid, 1.8-2 mm long, obtuse, near the tip of the column with a deltoid, rounded wing along the lower margin. Anther abaxially glabrous, front part slightly drawn out, margin truncate, slightly erose. Pollinia: the inner about as long as the outer, without appendages.

Colours - Median sepal and petals cream-coloured with red or purple dots. Lateral sepals whitish, yellowish green along the lower margins, blackish red along the upper margins towards the tip, with red or purple spots along the upper margin. Lip yellow, column yellow.

Habitat - Epiphyte in lowland rainforest. Altitude up to $300 \mathrm{~m}$. Flowering: March to May.

Distribution - Kalimantan Timur.

Notes - 1. Among the Borneo species, B. breimerianum is most similar to B. macranthum and $B$. praetervisum. It is unequivocally distinct at close inspection because of the retrorse 'horns' on the lip, as well as the rounded wings along the lower margin of the stelidia. Among species from elsewhere, B. grandifolium Schltr. is most similar, but this has a lip of $8-10.5 \mathrm{~mm}$ long.

2. The species is named in honour of Prof. Dr. D.D. Breimer, Rector Magnificus and President of the Leiden University, at the occasion of his retirement on 8 February 2007. He inspired the development of Pharmaceutical Research and the Bio-Sciences at Leiden University.

\section{REFERENCE}

Vermeulen, J.J. 2002. Bulbophyllum praetervisum J.J. Verm. (Orchidaceae), an overlooked species close to B. macranthum Lindl. Gard. Bull. Singapore 54: 153-154. 